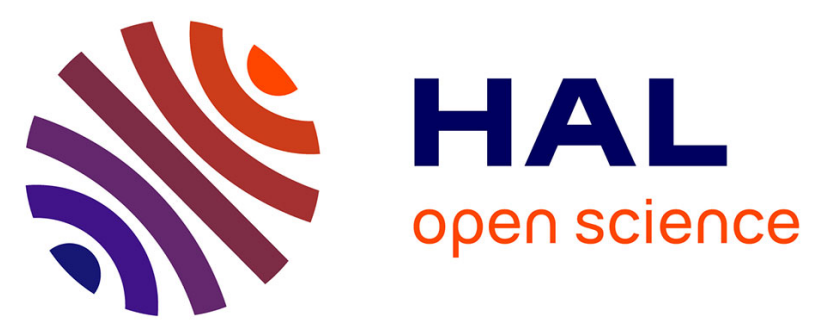

\title{
Metal-doped apatitic calcium phosphates: preparation, characterization, and reactivity in the removal of hydrogen sulfide from gas phase
}

Sonia Stita, Marta Galera Martinez, Huynh Pham Xuan, Doan Pham Minh, Ange Nzihou, Patrick Sharrock

\section{To cite this version:}

Sonia Stita, Marta Galera Martinez, Huynh Pham Xuan, Doan Pham Minh, Ange Nzihou, et al.. Metal-doped apatitic calcium phosphates: preparation, characterization, and reactivity in the removal of hydrogen sulfide from gas phase. Composite Interfaces , 2015, pp.1-22. 10.1080/09276440.2015.1049096 . hal-01150416

\section{HAL Id: hal-01150416 https://hal.science/hal-01150416}

Submitted on 11 May 2015

HAL is a multi-disciplinary open access archive for the deposit and dissemination of scientific research documents, whether they are published or not. The documents may come from teaching and research institutions in France or abroad, or from public or private research centers.
L'archive ouverte pluridisciplinaire HAL, est destinée au dépôt et à la diffusion de documents scientifiques de niveau recherche, publiés ou non, émanant des établissements d'enseignement et de recherche français ou étrangers, des laboratoires publics ou privés.

\section{(1)(1) $\$(0)$}

Distributed under a Creative Commons Attribution - NonCommercial - ShareAlikel 4.0 


\title{
Metal-doped apatitic calcium phosphates: preparation, characterization, and reactivity in the removal of hydrogen sulfide from gas phase
}

\author{
Sonia STITA ${ }^{1}$, Marta GALERA MARTINEZ ${ }^{1}$, Huynh PHAM XUAN ${ }^{1,2}$, Doan PHAM \\ MINH $^{1 *}$, Ange NZIHOU ${ }^{1}$, Patrick SHARROCK ${ }^{1}$ \\ ${ }^{1}$ Université de Toulouse, Mines Albi, CNRS UMR 5302, Centre RAPSODEE, Campus \\ Jarlard, F-81013 Albi cedex 09, France \\ ${ }^{2}$ Actual address: Renewable Energy Department, University of Science and Technology of \\ Hanoi, Vietnam \\ *Corresponding authors: Email: doan.phammin@mines-albi.fr, Tel: +33563493258.
}

Keywords: Hydroxyapatite; Metal deposition; Inorganic composite; Sorption; $\mathrm{H}_{2} \mathrm{~S}$ removal

\begin{abstract}
With the expansion of human activities, there are more and more living areas adjacent to industrial and/or agricultural activities such as chemical processes, petroleum processes, paint finishing, food processing, livestock farming, composting plants etc. Bad odor is part of several nuisances caused by industrial and/or agricultural activities. Hydrogen sulfide $\left(\mathrm{H}_{2} \mathrm{~S}\right)$ is a typical odorous molecule which causes foul odor at very low concentration. This molecule is formed in different industrial installations, in particular in coal combustion, and petrochemical refinery. The separation and/or transformation of $\mathrm{H}_{2} \mathrm{~S}$ from gas phase to odorless products are important processes for sustainable development.

In this paper, we communicate the preparation of new sorbents for the sorption of $\mathrm{H}_{2} \mathrm{~S}$ from a synthetic gas effluent. These sorbents consist in an inorganic phase (hydroxyapatite) as host particles, and well-dispersed particles of a metal oxide as guest particles which are the active phase for the removal of $\mathrm{H}_{2} \mathrm{~S}$. At room conditions, iron, lead and zinc doped calcium phosphates were found to be effective for the removal of $\mathrm{H}_{2} \mathrm{~S}$. The performance of the sorbents depends on preparation method and the nature of active phases. This opens new prospects for the treatment of $\mathrm{H}_{2} \mathrm{~S}$ from gas phase.
\end{abstract}

\section{Introduction}

Hydrogen sulfide $\left(\mathrm{H}_{2} \mathrm{~S}\right)$, a simple chemical molecule, is considered to be one of the most noxious gases. This malodorous compound exists in all environmental media: air, 
surface water, groundwater, soil, sediment etc. It can be found in different natural sources such as volcanic gas, geysers, sulphurous lakes etc. Nowadays, natural gas, biogas, and syngas being considered as important energy sources or raw materials (for syngas and hydrogen production), contain also $\mathrm{H}_{2} \mathrm{~S}$ at various concentrations, and need pre-treatment before being processed.[1-5] Different industrial processes and rural and agricultural activities generate also waste gases containing $\mathrm{H}_{2} \mathrm{~S}$, for examples, crude oil refineries, coal combustion and/or gasification, paper mills, food industries, wastewater treatment plants, animal farms, etc. At high concentration, the Claus process and its derivatives were developed for the recovery of sulphur.[6] At lower concentration, several methods for $\mathrm{H}_{2} \mathrm{~S}$ treatment and/or purification were developed. Biological processes call for the use of bacteria, such as Thiobacillus and Sulfolobus, for the oxidation of $\mathrm{H}_{2} \mathrm{~S}$ into elemental sulphur or sulphate.[7-9] However, these processes require strict operational conditions (temperature, pressure, input composition for energy source...).[10,11] Catalytic processes usually consist of the oxidation of $\mathrm{H}_{2} \mathrm{~S}$ over solid catalysts, in order to convert it to molecular sulphur, sulphide, thiosulfate, and sulphate.[12-14] Absorption and adsorption are also strongly developed for the elimination of $\mathrm{H}_{2} \mathrm{~S}$. Absorption refers to the process by which one substance (absorbent), such as a solid or a liquid, takes up $\mathrm{H}_{2} \mathrm{~S}$ in liquid or gas phase. Amine solutions are commonly used for the removal of $\mathrm{H}_{2} \mathrm{~S}$ from natural gas. They are attractive because of the potential for high removal efficiencies, their ability to be selective for $\mathrm{H}_{2} \mathrm{~S}$ abatement, and their regeneration possibility.[15-17] Adsorption relates to the fixation of $\mathrm{H}_{2} \mathrm{~S}$ on the surface of a solid by weak physical or physicochemical bonds. Different adsorbents having high reactivity, such as activated carbon, zeolites, modified alumina or other metal oxides, have been investigated for $\mathrm{H}_{2} \mathrm{~S}$ removal process.[2,18-20] As example, Florent and Bandosz investigated the performance of graphite oxide supported cobalt oxyhydroxyde $(\mathrm{CoOOH} / \mathrm{C})$ for the treatment of $\mathrm{H}_{2} \mathrm{~S}$ in moist or dry air.[20] The adsorption capacity of this adsorbent up to reached 69.1 $\mathrm{mg} \mathrm{g}^{-1}$. In addition to these standard methods for $\mathrm{H}_{2} \mathrm{~S}$ treatment, hydrate technology has been developed for $\mathrm{H}_{2} \mathrm{~S}$ separation. Details of this technology can be found elsewhere.[5] This technology was found to be efficient for cleaning and upgrading the biogas. However, because of their relatively high cost, currently, there has been an increasing interest in utilizing low cost adsorbents which leads to screening industrial wastes, agricultural byproducts and natural materials as alternative adsorbents.[21]

This study aims to investigate the reactivity of zinc-, lead-, and iron-doped hydroxyapatites for the removal of $\mathrm{H}_{2} \mathrm{~S}$ from gas phase at room pressure and temperature. 
Hydroxyapatite $\left(\mathrm{Ca}_{10}\left(\mathrm{PO}_{4}\right)_{6}(\mathrm{OH})_{2}\right.$, called thereafter $\left.\mathrm{CaP}\right)$ can be easily synthesized from a calcium source and a phosphate source such as calcium hydroxide and phosphoric acid.[22] But it can also be obtained from solid wastes such as egg shells, animal bones [23-25] allowing the access to low-cost materials. It has the advantage of being thermally stable and being adapted for the deposition of well-dispersed metal particles by different methods, including the conventional incipient wetness impregnation (IWI), and also the ionic exchange (CEX) thanks to its high affinity for metal cations such as $\mathrm{Zn}, \mathrm{Pb}, \mathrm{Fe} .[26-29]$ The influence of the preparation method for the deposition of metals on CaP support, and the influence of the nature of the metals on the performance of functionalized solids for $\mathrm{H}_{2} \mathrm{~S}$ removal in gas phase is the subject of this communication.

\section{Materials and methods}

\subsection{Materials}

A commercial apatitic calcium phosphate (specific surface area: $7 \mathrm{~m}^{2} / \mathrm{g}$ ) powder was used as received for the preparation of metal-doped calcium phosphate sorbents. An activated carbon (L3S, from CECA, $800 \mathrm{~m}^{2} \mathrm{~g}^{-1}$ ) was also used as reference for $\mathrm{H}_{2} \mathrm{~S}$ removal.

Iron(III) nitrate nonahydrate $\left(\mathrm{Fe}\left(\mathrm{NO}_{3}\right)_{3} \cdot 9 \mathrm{H}_{2} \mathrm{O}, 98.2 \%\right.$, Fisher Scientific), lead(II) nitrate $\left(\mathrm{Pb}\left(\mathrm{NO}_{3}\right)_{2}, 99.8 \%\right.$, Fisher Scientific) and zinc nitrate hexahydrate $\left(\mathrm{Zn}\left(\mathrm{NO}_{3}\right)_{2} \cdot 6 \mathrm{H}_{2} \mathrm{O}\right.$, $>97 \%$, Fisher Scientific) were purchased and used without further purification.

\subsection{Synthesis of metal-doped sorbents}

The synthesis of metal-doped sorbents was the same as described elsewhere by Galera Martinez et al.[30] Using CEX method (cation exchange), $39 \mathrm{~g}$ of CaP powder were put into 2 $\mathrm{L}$ of the metal nitrate solution of defined concentration under stirring at $500 \mathrm{rpm}$. After $4 \mathrm{~h}$ of contact, the suspension was filtered and the resulting solid was washed several times with permuted water and dried in ambient air. Using IWI method (incipient wetness impregnation), an aqueous solution of metal precursor was prepared. The volume and the concentration of this solution were calculated in order to just wet the powder, and the desired metal content (0.7 or 1 wt.\%) in the final product. The impregnation of the $\mathrm{CaP}$ powder with the metal precursor solution resulted in the formation of a doughy mixture. This last one was dried at ambient conditions. For both methods used, the dried metal-doped solids were fired at 450$500{ }^{\circ} \mathrm{C}$ for $1 \mathrm{~h}$.

Samples were designated according to: (i) the method of preparation (CEX or IWI); (ii) the metal doped. For example, CEX-Fe corresponds to Fe-doped CaP prepared by CEX 
method. Three metals $\left(\mathrm{Fe}^{3+}, \mathrm{Pb}^{2+}\right.$, and $\left.\mathrm{Zn}^{2+}\right)$ were selected to prepare the sorbents, because of their availability, their low cost and their high affinity for sulphur compounds.

\subsection{Characterizations}

Inductively coupled plasma-atomic emission spectrometry analysis (ICP-AES) was performed using a HORIBA Jobin Y von Ultima 2 for the analysis of metals contents of the prepared solids. Solid samples were dissolved in a mixture of $\mathrm{HCl}$ and $\mathrm{HNO}_{3}$ acids before analysis. Scanning electron microscopy (SEM) observation was carried out with a Philips XL30 FEG microscope. TEM-EDS analysis was carried out using a FEG JEOL JEM 2100F, equipped with a HAADF detector. This TEM apparatus is coupled with an EDS BRUKER which is equipped with a SDD detector (SDD of $127 \mathrm{eV}$ resolution) for the analysis of elements on the surface of the solids. 2.4. Removal of $\mathrm{H}_{2} \mathrm{~S}$ from gas phase

$\mathrm{H}_{2} \mathrm{~S}$ removal experiments were carried out at room temperature and atmospheric pressure. For each experiment, $500 \mathrm{mg}$ of sorbent sample was set into a glass fixed-bed reactor (i.d. of $15 \mathrm{~mm}$ ). Figure 1 illustrates the configuration of the experimental setup. Synthetic gas effluents were purchased from Air Liquide (France). These effluents consist of dried air containing 50 or 200 ppmv of $\mathrm{H}_{2} \mathrm{~S}$. For a given experiment, the synthetic gas effluent was passed through the sorbent bed at the flow rate of $50 \mathrm{~mL} / \mathrm{min}$. The concentration of $\mathrm{H}_{2} \mathrm{~S}$ in the outlet gas stream was monitored using an electrochemical detector (GasAlertQuatro, BW Technologies), which recorded $\mathrm{H}_{2} \mathrm{~S}$ concentration every $60 \mathrm{~s}$, and which has the detection limit of $0.1 \mathrm{ppm}$.

\section{Figure 1}

In this work, the following terms were used in order to compare different sorbents and different experimental conditions:

- $m_{\mathrm{H}_{2} \mathrm{~S}}^{\text {inlet }}(\mathrm{mg})$ : the total quantity $\mathrm{H}_{2} \mathrm{~S}$ injected to the reactor at a given reaction time.

- $m_{\mathrm{H}_{2} \mathrm{~S}}^{\text {sorbent }}(\mathrm{mg})$ : the total quantity $\mathrm{H}_{2} \mathrm{~S}$ fixed on the sorbent at a given reaction time.

- $t_{100 \%}$ (min): the reaction time wherein the removal of $\mathrm{H}_{2} \mathrm{~S}$ was total. So, theoretically $m_{H_{2} S}^{\text {inlet }}$ is equal to $m_{H_{2} S}^{\text {sorbent }}$ within $t_{100 \%}$.

- $t_{b t h}$ (breakthrough time, min): the time from the beginning of the experiment to the point where the outlet concentration raised to $75 \%$ of the inlet concentration. Theoretically, $t_{b t h}$ is longer than $t_{100 \%}$. 
The calculation of $m_{\mathrm{H}_{2} \mathrm{~S}}^{\text {inlet }}$ and $m_{\mathrm{H}_{2} \mathrm{~S}}^{\text {sorbent }}$ were done with the Eqs. 1 to 2, respectively:

$$
\begin{aligned}
& m_{H_{2} S}^{\text {inlet }}=\frac{P Q M}{10^{6} R T} C_{\mathrm{int}} t \\
& m_{\mathrm{H}_{2} S}^{\text {sorbent }}=\frac{P Q M}{10^{6} R T}\left[C_{\mathrm{int}} t-\int_{0}^{t} C_{\text {out }} d t\right]
\end{aligned}
$$

where $Q$ : inlet flow rate $(\mathrm{L} / \mathrm{min}), M$ : the molecular weight of $\mathrm{H}_{2} \mathrm{~S}(34.06 \mathrm{mg} / \mathrm{mmol})$, $W$ : mass of sorbent used (g), $V_{M}$ : molar gas volume at $20{ }^{\circ} \mathrm{C}$ and 1 atm $(\mathrm{L} / \mathrm{mmol}), C_{i n}$ : inlet concentration of $\mathrm{H}_{2} \mathrm{~S}(50$ or $200 \mathrm{ppm}), C_{\text {out }}$ : outlet concentration of $\mathrm{H}_{2} \mathrm{~S}$ (ppm), t: time-onstream (min).

\section{Results and discussion}

\subsection{Characterization of the sorbents}

Figure 2 reports the ICP-AES analysis results of the metal contents of the sorbents. For iron and zinc, their theoretical contents were $1 \mathrm{wt} . \%$. On the other hand, the theoretical content of lead was $0.7 \mathrm{wt} . \%$. As expected, IWI method was effective for the deposition of all three metals. The metal contents obtained by ICP-AES analysis were close to the theoretical values. In fact, the only metal loss during this deposition method might be due to metal deposition on the flask wall. For the deposition of iron using CEX method, high deposition level was also observed. When $\mathrm{CaP}$ was added into the iron(III) nitrate solution for cationic exchange, the $\mathrm{pH}$ increased immediately to about 6 . In these conditions, iron(III) could be exchanged with $\mathrm{Ca}(\mathrm{II}),[31]$ and could be also precipitated on the surface of $\mathrm{CaP}$ particles. On the other hand, CEX method allowed only the partial deposition of lead(II) and zinc(II). This could be due to the low specific surface area of the commercial $\mathrm{CaP}$ used in this work, which was $7 \mathrm{~m}^{2} / \mathrm{g}$.

Figure 2

All metal-doped CaP samples were characterized by XRD method, after calcination under air atmosphere at $400-500{ }^{\circ} \mathrm{C}$ for $2 \mathrm{~h}$. No diffraction of the metals-based products (iron, lead, zinc) was observed, which can be explained by their low contents (less than 1 wt.\%) and/or their high dispersion or amorphous form (XRD results not shown). All these samples show similar patterns compared to the initial CaP support. So the metal deposition by CEX or IWI methods, followed by calcination step did not change the apatitic crystalline structure of the initial support. 
Figure 3

In order to identify the presence of metals on the surface of CaP support, SEM and TEM analyses were performed. Figure 3 illustrates SEM images of different solids obtained by CEX and IWI methods. Both lead-doped $\mathrm{CaP}$ solids (CEX-Pb and IWI-Pb) and zinc-doped CaP solid by IWI (IWI-Zn) showed lead and zinc based particles at micrometric scale. These particles had higher contrast, so higher brightness, compared to other elements present on $\mathrm{CaP}$ surface. In fact, IWI method is expected to deposit metal particles on the surface of the support. On the other hand, the formation of lead-based particle in CEX-Pb sample might be due to the agglomeration of lead during the thermal treatment.

Both iron-doped CaP solids (CEX-Fe and IWI-Fe) and zinc-doped CaP solid by CEX method did not show visible metals particles at micrometric scale. This could correspond to a high dispersion of these metals on the surface of $\mathrm{CaP}$ support and their thermal stability during the calcination under air atmosphere. To confirm it, TEM analysis of iron-doped CaP by IWI method was performed (Figure 4). The distribution of all elements present on this solid including $\mathrm{P}, \mathrm{O}, \mathrm{Ca}, \mathrm{Fe}$ was also recorded. By contrast difference, TEM image shows the formation of iron clusters at nano-scale which had higher contrast than other elements of the $\mathrm{CaP}$ support (top, left-hand-side). By EDS analysis using SDD detector, $\mathrm{P}, \mathrm{O}$ and $\mathrm{Ca}$ were homogeneously distributed on the surface of the particles. Iron could also be identified and it did not cover the entire surface of the support. The superposition of phosphorus, oxygen and iron demonstrates that iron was deposited on the surface of the CaP support (bottom, righthand-side).

Figure 4

\subsection{Removal of $\mathrm{H}_{2} \mathrm{~S}$ diluted in air}

Figure 5 shows the results obtained for the synthetic effluent containing 200 ppmv of $\mathrm{H}_{2} \mathrm{~S}$ in dry air atmosphere. As mentioned previously, for each sorbent, $\mathrm{H}_{2} \mathrm{~S}$, Accumulated inlet curve (Fig. 5 (a)) was superposed with the curve expressing the total quantity of $\mathrm{H}_{2} \mathrm{~S}$ captured by the sorbent within $t_{100 \%}$ period. The initial CaP support showed very low reactivity under the experimental conditions used, with $t_{b t h}$ and $t_{100 \%}$ equal to 4 and $<1 \mathrm{~min}$, respectively. On the other hand, doping with metals increased strongly the reactivity of the initial $\mathrm{CaP}$, with $t_{b t h}$ and $t_{100 \%}$ varying in the range of 22-168 and 2-15 min, respectively. The comparison of $t_{b t h}$ for all metals-doped $\mathrm{CaP}$ reveals that, for each metal, the solids prepared by IWI method were systematically more active than those prepared by CEX method. This observation was also 
similar for the comparison of $t_{100 \%}$ obtained with these sorbents. In fact, IWI led to the formation of dispersed metal-oxide particles on the surface of $\mathrm{CaP}$ support, which could react with $\mathrm{H}_{2} \mathrm{~S}$ molecules. On the other hand, CEX method theoretically led to the insertion of metal cations into and inside the apatitic structure of $\mathrm{CaP}$, which probably became inert and unavailable for the fixation of $\mathrm{H}_{2} \mathrm{~S}$, when not localized on the surface. Among the prepared sorbents, $\mathrm{CaP}$ doped with iron by IWI (IWI-Fe) was the most active for $\mathrm{H}_{2} \mathrm{~S}$ removal, regarding both $t_{100 \%}$ and $t_{b t h}$ (Figure 5). After $260 \mathrm{~min}$ of time-on-stream, this sorbent was completely saturated and the sorption capacity could be calculated, which reached $3.9 \mathrm{mg}$ of $\mathrm{H}_{2} \mathrm{~S}$ per gram of IWI-Fe.

Figure 5

The comparison of $t_{100 \%}$ and $t_{b t h}$ for each sorbent shows that, under the experimental conditions used, there were big gaps between $t_{100 \%}$ and $t_{b t h}$ for all the sorbents. This suggests slow kinetics for the $\mathrm{H}_{2} \mathrm{~S}$-sorbent interaction under the experimental conditions used. Increasing contact time by decreasing gas flow rate or by increasing sorbent volume may reduce these gaps between $t_{100 \%}$ and $t_{b t h}$.

From the results obtained in Figure 5, three sorbents prepared by IWI method were selected for testing with synthetic gas effluent containing lower $\mathrm{H}_{2} \mathrm{~S}$ concentration. Their reactivity was compared with a commercial activated carbon (L3S powder, from CECA, France) as reference. Figure 6 confirms that the initial $\mathrm{CaP}$ had low reactivity for the abatement of $\mathrm{H}_{2} \mathrm{~S}$ with negligible $t_{100 \%}$, even with lower $\mathrm{H}_{2} \mathrm{~S}$ concentration of $50 \mathrm{ppmv}$. As expected, doping with metals made the sorbents much more active, with $t_{100 \%}$ equal to 31,67 , and 85 min for the sorbents doped with $\mathrm{Zn}, \mathrm{Fe}$, and $\mathrm{Pb}$, respectively. The reactivity of the $\mathrm{CaP}$ doped with metals was comparable to that of this activated carbon. This last one showed $t_{100 \%}$ of $67 \mathrm{~min}$, which was equal to the value obtained with IWI-Fe. Contrary to the results obtained with synthetic air containing 200 ppmv of $\mathrm{H}_{2} \mathrm{~S}$, IWI-Pb was found to be the most efficient sorbent for synthetic air containing $50 \mathrm{ppmv}$ of $\mathrm{H}_{2} \mathrm{~S}$. Standard characterizations such as SEM-EDS, XRD, FTIR, TG-DSC were performed with sorbents recovered after sorption tests. However, since the content of sulphur compounds was low in the used sorbents, these characterization techniques did not allow explaining this observation. Further analysis is needed in order to understand these results.

Figure 6

\subsection{Reactivation of saturated sorbent and sorption capacity}


The saturated IWI-Fe sorbent recovered from the first test was thermally treated by calcination at $500{ }^{\circ} \mathrm{C}$ for $2 \mathrm{~h}$. This temperature was chosen because it was the firing temperature for the preparation of the initial IWI-Fe sorbent. The objective was to release the sulfur species from the surface of the saturated sorbent. The regenerated sorbent was used again for hydrogen sulfide removal under the same experimental conditions (the $1^{\text {st }}$ recycling). This regeneration procedure was repeated for the $2^{\text {nd }}$ recycling. The results are presented in the Figure 7.

\section{Figure 7}

At this regeneration temperature $\left(500^{\circ} \mathrm{C}\right)$, IWI-Fe sorbent lost about one third of its reactivity at the first recycling. $t_{100 \%}$ decreased from 67 to $44 \mathrm{~min}$. The observation was similar at the second recycling wherein $t_{100 \%}$ decreased from 44 to $30 \mathrm{~min}$. So, about one third of available active sites (iron oxides) on the surface of HAP particles could not be reactivated at each recycling. This might be due to the formation of strong chemical bond between sulfur species and active sites, which could not be released by the calcination at $500{ }^{\circ} \mathrm{C}$. This might be also due to the agglomeration of iron-based particles during the regeneration step at 500 ${ }^{\circ} \mathrm{C}$, forming bigger iron-based particles and so reducing the dispersion of the active phase.

Figure 8

Reactivation study was also performed with the saturated activated carbon. After the first test with the fresh sorbent, the resulting saturated sorbent was regenerated by calcination at $400{ }^{\circ} \mathrm{C}$ under air atmosphere for $2 \mathrm{~h}$. This regenerated sorbent was tested again under the same experimental conditions. The value of $t_{100 \%}$ of $49 \mathrm{~min}$ was obtained at the $1^{\text {st }}$ recycling. This indicates the similar reactivity of the reactivated carbon to IWI-Fe. The reactivity loss of the activated carbon might be due to the presence of irreversible interaction between sulfurbased species with active sites, or the partial destruction of active sites on the surface of the sorbent during calcination step.

\section{Conclusions}

Metals-doped apatitic calcium phosphates (HAP) were prepared by cationic exchange (CEX) and incipient wetness impregnation (IWI) methods. Metals-based particles could be observed at micrometric scale using SEM technique for lead- and zinc-doped HAP. On the other hand, iron-doped HAP contained particles at nanometric scale and were observed by TEM technique. For the removal of $\mathrm{H}_{2} \mathrm{~S}$ diluted in air atmosphere, the initial HAP showed very low reactivity. The addition of a metal such as lead, iron and zinc improved strongly the 
reactivity of this initial HAP. For each metal, sorbents prepared by IWI method were found to be more reactive than those prepared by CEX method. IWI preparation led to the formation of dispersed metal particles which have available and reactive surfaces for $\mathrm{H}_{2} \mathrm{~S}$ fixation. On the other hand, CEX method led to the incorporation of metals in the CaP structure which makes the metal less available for the fixation of $\mathrm{H}_{2} \mathrm{~S}$. The sorbent containing only $0.77 \mathrm{wt} . \%$ of iron and prepared by IWI method (IWI-Fe) had the similar reactivity compared to an activated carbon under the same experimental conditions. The reactivation of this sorbent (IWI-Fe) by calcination at $500{ }^{\circ} \mathrm{C}$, after $\mathrm{H}_{2} \mathrm{~S}$ removal test, allowed recovering two thirds of its reactivity. This signifies the possible presence of irreversible interaction of sulfur-based species with the sorbent.

Future work will focus on the optimization of metal deposition for the formation of highly-dispersed metal particles at nanometric scale, and also on the influence of the contact time by changing the volume of sorbent's bed. Other regeneration methods may be also investigated. The removal of $\mathrm{H}_{2} \mathrm{~S}$ at high temperature, for example for the purification of hot syngas generated from thermal gasification of biomass, seems to be particularly interesting because of high thermal stability of hydroxyapatite-based materials, as demonstrated previously.[30]

Acknowledgment

The authors gratefully acknowledge colleagues at RAPSODEE Center for technical help.

\section{References}

[1] Marzouk SAM, Al-Marzouqi MH, Teramoto M, Abdullatif N, Ismail ZM. Simultaneous removal of $\mathrm{CO}_{2}$ and $\mathrm{H}_{2} \mathrm{~S}$ from pressurized $\mathrm{CO}_{2}-\mathrm{H}_{2} \mathrm{~S}-\mathrm{CH}_{4}$ gas mixture using hollow fiber membrane contactors. Sep. Purif. Technol. 2012;86:88-97.

[2] Maghsoudi H, Soltanieh M. Simultaneous separation of $\mathrm{H}_{2} \mathrm{~S}$ and $\mathrm{CO}_{2}$ from $\mathrm{CH}_{4}$ by a high silica CHA-type zeolite membrane. J. Membrane Sci. 2014;470:159-165.

[3] Hao J, Rice PA, Stern SA. Upgrading low-quality natural gas with $\mathrm{H}_{2} \mathrm{~S}$ - and $\mathrm{CO}_{2}$-selective polymer membranes Part II. Process design, economics, and sensitivity study of membrane stages with recycle streams. J. Membrane Sci. 2008;320:108-122.

[4] Mondal P, Dang GS, Garg MO. Syngas production through gasification and cleanup for downstream applications - Recent developments. Fuel Process. Technol. 2011;92:13951410 . 
[5] Castellani B, Rossi F, Filipponi M, Nicolini A. Hydrate-based removal of carbon dioxide and hydrogen sulphide from biogas mixtures: Experimental investigation and energy evaluations, Biomass Bioenergy 2014;70:330-338.

[6] Rezazadeh R, Rezvantalab S. Investigation of inlet gas streams effect on the modified Claus reaction furnace. Adv. Chem. Eng. Sci. 2013;3:6-14.

[7] Sublette KL. Oxidation of hydrogen sulfide by continuous cultures of Thiobacillus denitrificans. Biotechnol. Bioeng. 1987;XXIX:753-758.

[8] Oyarzun P, Arancibia F, Canales C, Aroca GE. Biofiltration of high concentration of hydrogen sulphide using Thiobacillus thioparus. Process Biochem. 2003;39:165-170.

[9] Morales M, Arancibia J, Lemus M, Silva J, Gentina JC, Aroca G. Bio-oxidation of $\mathrm{H}_{2} \mathrm{~S}$ by Sulfolobus metallicus. Biotechnol. Lett. 2011;33:2141-2145.

[10] Omri I, Aouidi F, Bouallagui H, Godon JJ, Hamdi M. Performance study of biofilter developed to treat $\mathrm{H}_{2} \mathrm{~S}$ from wastewater odour. Saudi J. Biol. Sci. 2013;20:169-176.

[11] Lebrero R, Gondim AC, Perez R, Garcia-Encina PA, Munoz R. Comparative assessment of a biofilter, a biotrickling filter and a hollow fiber membrane bioreactor for odor treatment in wastewater treatment plants. Wat. Res. 2014;49:339-350.

[12] Goifman A, Gun J, Gelman F, Ekeltchik I, Leva O, Donner J, Bornick H, Worch E. Catalytic oxidation of hydrogen sulfide by dioxygen on $\mathrm{CoN}_{4}$ type catalyst. Appl. Catal. B: Environ. 2006;63:296-304.

[13] Bineesh KV, Kim DK, Kim MI, Park DW. Selective catalytic oxidation of $\mathrm{H}_{2} \mathrm{~S}$ over $\mathrm{V}_{2} \mathrm{O}_{5}$ supported on $\mathrm{TiO}_{2}$-pillared clay catalysts in the presence of water and ammonia. Appl. Clay Sci. 2011;53:204-211.

[14] Duong-Viet C, Truong-Phuoc L, Tran-Thanh T, Nhut JM, Nguyen-Dinh L, Janowska I, Begin D, Pham-Huu C. Nitrogen-doped carbon nanotubes decorated silicon carbide as ametal-free catalyst for partial oxidation of $\mathrm{H}_{2}$ S. Appl. Catal. A: Gen. 2014;482:397-406.

[15] Astarita G, Gioia F, Balzano C. Hydrogen sulphide absorption in aqueous monoethanolamine solutions. Chem. Eng. Sci. 1965;20:1101-1105.

[16] Kohl AL, Nielsen RB. Chapter 2 - alkanolamines for hydrogen sulfide and carbon dioxide removal. In: Gas Purification. $5^{\text {th }}$ Ed. Gulf Professional Publishing; 1997. p. 40186.

[17] Haghtalab A, Izadi A. Simultaneous measurement solubility of carbon dioxide + hydrogensulfide into aqueous blends of alkanolamines at high pressure. Fluid Phase Equilibr. 2014;375:181-190. 
[18] Song HS, Park MG, Ahn W, Lim SN, Yi KB, Croiset E, Chen Z, Name SC. Enhanced adsorption of hydrogen sulfide and regeneration ability on the composites of zinc oxide with reduced graphite oxide. Chem. Eng. J. 2014;253:264-273.

[19] Arespacochaga N, Valderrama C, Mesa C, Bouchy L, Cortina JL. Biogas deep clean-up based on adsorption technologies for solid oxide fuel cell applications. Chem. Eng. J. 2014;255:593-603.

[20] Florent M, Bandosz TJ. Effects of surface heterogeneity of cobalt oxyhydroxide/graphite oxide composites on reactive adsorption of hydrogen sulphide. Microporous Mesoporous Mater. 2015;204:8-14.

[21] Ri JN, Sub SH, Gyu PM, Jin KS, Jeong RH, Bok YK. Effect of reduced graphite oxide as substrate for zinc oxide to hydrogen sulfide adsorption. Clean Technol. 2013;19:300305.

[22] Pham Minh D, Nzihou A, Sharrock P. Carbonated hydroxyapatite starting from calcite and different orthophosphates under moderate hydrothermal conditions: Synthesis and surface reactivity in simulated body fluid. Mater. Res. Bull. 2014;60:292-299.

[23] Chaudhuri B, Mondal B, Modak DK, Pramanik K, Chaudhuri BK. Preparation and characterization of nanocrystalline hydroxyapatite from egg shell and $\mathrm{K}_{2} \mathrm{HPO}_{4}$ solution. Mater. Lett. 2013;97:148-150.

[24] Figueiredo M, Fernando A, Martins G, Freitas J, Judas F, Figueiredo H. Effect of the calcination temperature on the composition and microstructure of hydroxyapatite derived from human and animal bone. Ceram. Int. 2010;36:2383-2393.

[25] Sasakin K, Goto T. Immobilization of $\mathrm{Sr}^{2+}$ on naturally derived hydroxyapatite by calcinations of different species of fish bones and influence of calcinations on ionexchange efficiency. Ceram. Int. 2014;40:11649-11656.

[26] Sheha RR. Sorption behavior of Zn(II) ions on synthesized hydroxyapatites. J. Colloid Interf. Sci. 2007;310:18-26.

[27] Pham Minh D, Tran ND, Nzihou A, Sharrock P. Calcium phosphate based materials starting from calcium carbonate and orthophosphoric acid for the removal of lead(II) from an aqueous solution. Chem. Eng. J. 2014;243:280-288.

[28] Mobasherpour I, Salahi E, Pazouki M. Comparative of the removal of $\mathrm{Pb}^{2+}, \mathrm{Cd}^{2+}$ and $\mathrm{Ni}^{2+}$ by nano crystallite hydroxyapatite from aqueous solutions: adsorption isotherm study. Arab. J. Chem. 2012;5:439-446. 
[29] Kramer E, Zilm M, Wei M. A comparative study of the sintering behavior of pure and iron-substituted hydroxyapatite. Bioceram. Dev. Appl. 2013 ;3:article N ${ }^{\circ} 1000067$ (9 pages).

[30] Galera Martínez M, Pham Minh D, Weiss-Hortala E, Nzihou A, Sharrock P. Compos. Interfaces 2013;20:647-660.

[31] Kousalya GN, Gandhi MR, Sundaram CS, Meenakshi S. Synthesis of nanohydroxyapatite chitin/chitosan hybrid biocomposites for the removal of $\mathrm{Fe}(\mathrm{III})$. Carbohyd. Polym. 2010;82:594-599. 
Table and figure captions

Figure 1. Experimental setup for $\mathrm{H}_{2} \mathrm{~S}$ removal from gas phase.

Figure 2. Metals contents of the prepared sorbents obtained by ICP-AES analysis.

Figure 3. SEM images of the prepared sorbents.

Figure 4. TEM image of IWI-Fe (top, left-hand-side) and the corresponding distribution of O, $\mathrm{P}, \mathrm{Ca}$ and $\mathrm{Fe}$.

Figure 5. Performance of the prepared sorbents for the removal of $\mathrm{H}_{2} \mathrm{~S}$ (200 ppmv) diluted in air. Experimental conditions: room temperature and pressure, $500 \mathrm{mg}$ of sorbent, $50 \mathrm{~mL} / \mathrm{min}$ of gas effluent. (a): " $\mathrm{H}_{2} \mathrm{~S}$, Accumulated inlet" curve: total quantity of $\mathrm{H}_{2} \mathrm{~S}$ injected in the reactor (or $m_{\mathrm{H}_{2} \mathrm{~S}}^{\text {inlet }}$ ); other curves: total quantity of $\mathrm{H}_{2} \mathrm{~S}$ captured by the sorbents (or $m_{\mathrm{H}_{2} \mathrm{~S}}^{\text {sorbent }}$ ); (b) Times for the complete removal of $\mathrm{H}_{2} \mathrm{~S}\left(t_{100 \%}\right)$ and breakthrough time $\left(t_{b t h}\right)$.

Figure 6. Performance of the prepared sorbents and an activated carbon as reference for the removal of $\mathrm{H}_{2} \mathrm{~S}$ (50 ppmv) diluted in air. Experimental conditions: room temperature and pressure, $500 \mathrm{mg}$ of sorbent, $50 \mathrm{~mL} / \mathrm{min}$ of gas effluent. (a): “ $\mathrm{H}_{2} \mathrm{~S}$, Accumulated inlet" curve: total quantity of $\mathrm{H}_{2} \mathrm{~S}$ injected in the reactor (or $m_{\mathrm{H}_{2} \mathrm{~S}}^{\text {inlet }}$ ); other curves: total quantities of $\mathrm{H}_{2} \mathrm{~S}$ captured by the sorbents (or $m_{\mathrm{H}_{2} \mathrm{~S}}^{\text {sont }}$ ); (b): (b) Times for the complete removal of $\mathrm{H}_{2} \mathrm{~S}\left(t_{100 \%}\right)$. Figure 7. Regeneration study of the saturated IWI-Fe sorbent for the removal of $\mathrm{H}_{2} \mathrm{~S}$ (50 ppmv) diluted in air. Regeneration procedure: calcination of saturated sorbent in air atmosphere at $500{ }^{\circ} \mathrm{C}$. Experimental conditions: room temperature and pressure, $500 \mathrm{mg}$ of sorbent, $50 \mathrm{~mL} / \mathrm{min}$ of gas effluent. " $\mathrm{H}_{2} \mathrm{~S}$, Accumulated inlet" curve: total quantity of $\mathrm{H}_{2} \mathrm{~S}$ injected in the reactor (or $m_{\mathrm{H}_{2} \mathrm{~S}}^{\text {inlet }}$ ) other curves: total quantities of $\mathrm{H}_{2} \mathrm{~S}$ captured by the sorbents (or $m_{H_{2} S}^{\text {sorbent }}$ ).

Figure 8. Regeneration study of the saturated activated carbon sorbent for the removal of $\mathrm{H}_{2} \mathrm{~S}$ (50 ppmv) diluted in air. Regeneration procedure: calcination of saturated sorbent in air atmosphere at $500{ }^{\circ} \mathrm{C}$. Experimental conditions: room temperature and pressure, $500 \mathrm{mg}$ of sorbent, $50 \mathrm{~mL} / \mathrm{min}$ of gas effluent. " $\mathrm{H}_{2} \mathrm{~S}$, Accumulated inlet" curve: total quantity of $\mathrm{H}_{2} \mathrm{~S}$ injected in the reactor (or $m_{\mathrm{H}_{2} \mathrm{~S}}^{\text {inlet }}$ ) other curves: total quantities of $\mathrm{H}_{2} \mathrm{~S}$ captured by the sorbents (or $m_{H_{2} S}^{\text {sorbent }}$ ). 


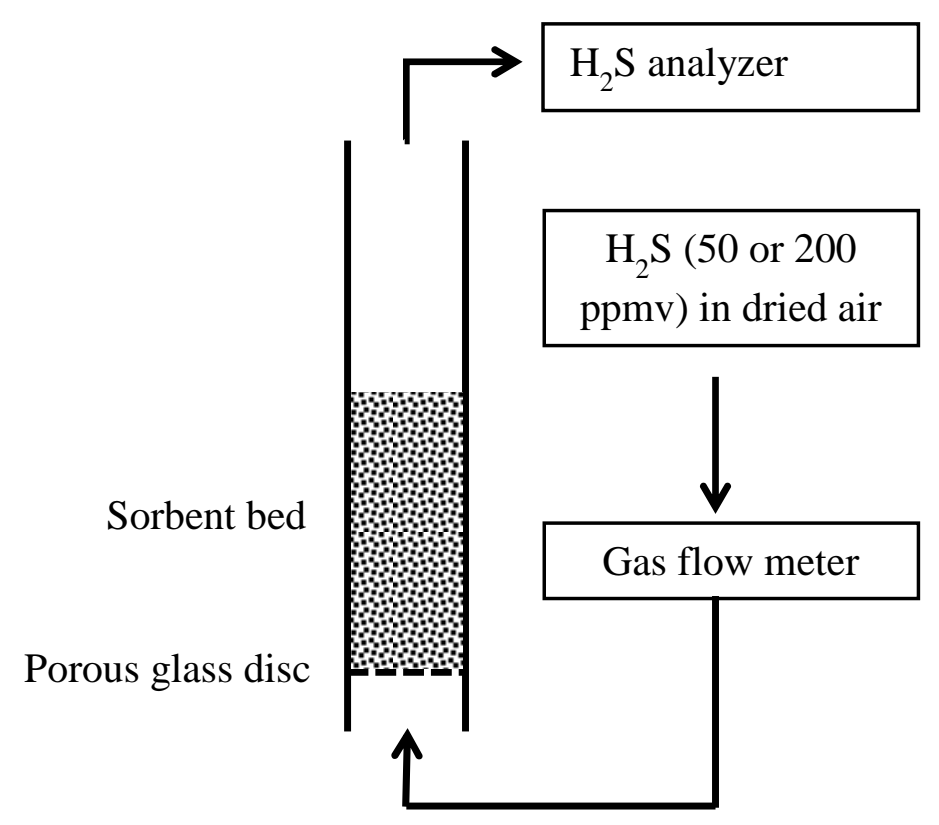

Figure 1. Experimental setup for $\mathrm{H}_{2} \mathrm{~S}$ removal from gas phase. 


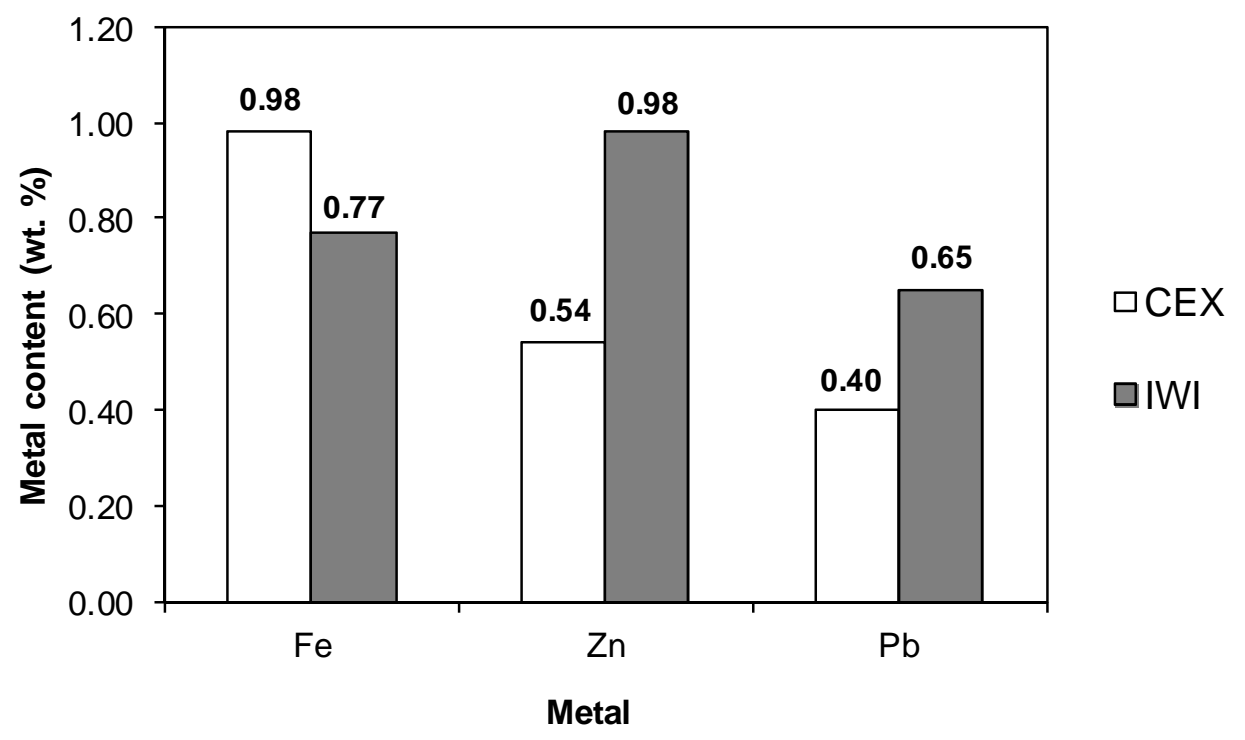

Figure 2. Metals contents of the prepared sorbents obtained by ICP-AES analysis. 

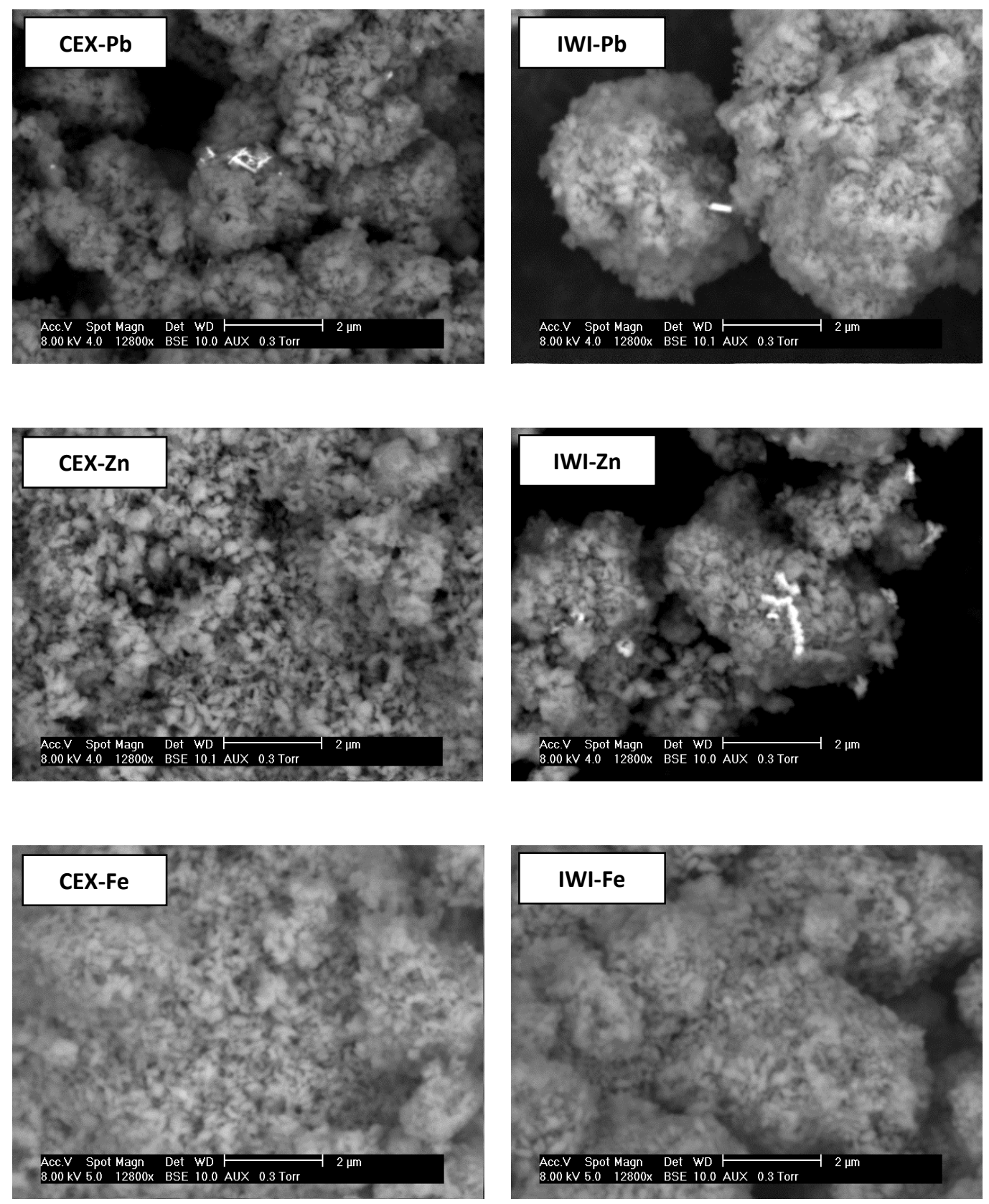

Figure 3. SEM images of the prepared sorbents. 

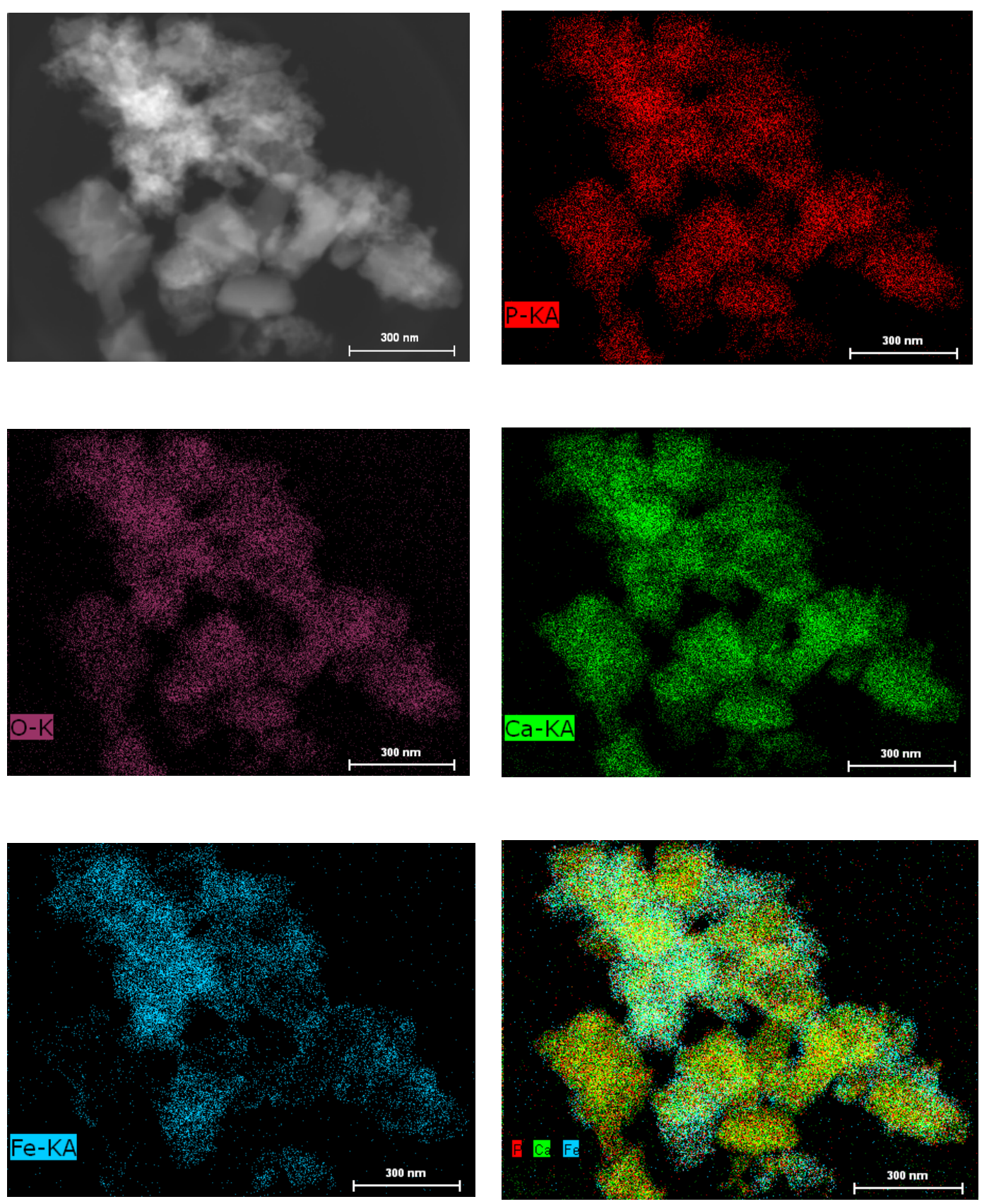

Figure 4. TEM image of IWI-Fe (top, left-hand-side) and the corresponding distribution of O, $\mathrm{P}, \mathrm{Ca}$ and $\mathrm{Fe}$. 

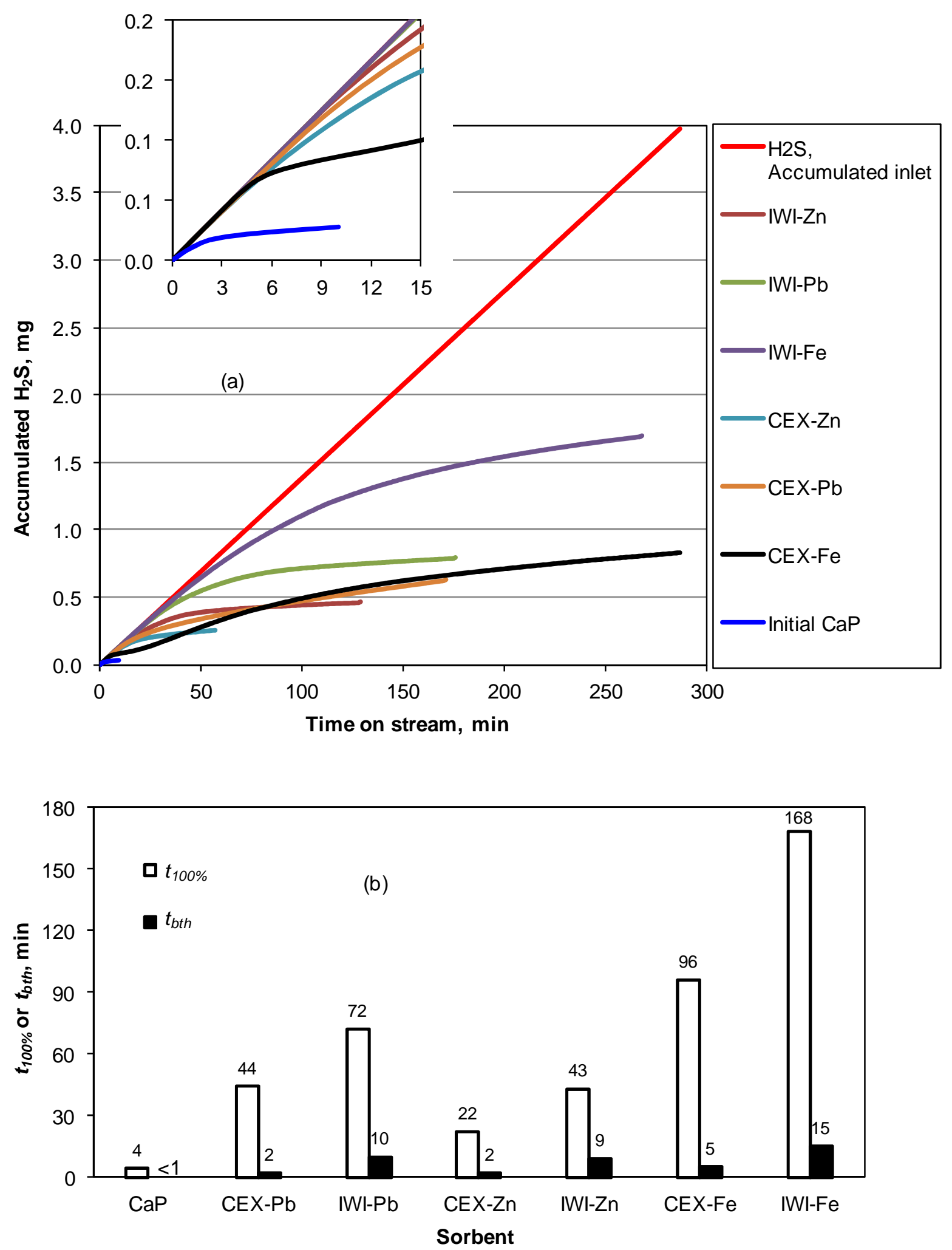

Figure 5. Performance of the prepared sorbents for the removal of $\mathrm{H}_{2} \mathrm{~S}$ (200 ppmv) diluted in air. Experimental conditions: room temperature and pressure, $500 \mathrm{mg}$ of sorbent, $50 \mathrm{~mL} / \mathrm{min}$ of gas effluent. (a): " $\mathrm{H}_{2} \mathrm{~S}$, Accumulated inlet" curve: total quantity of $\mathrm{H}_{2} \mathrm{~S}$ injected in the 
reactor (or $m_{\mathrm{H}_{2} \mathrm{~S}}^{\text {inlet }}$ ); other curves: total quantity of $\mathrm{H}_{2} \mathrm{~S}$ captured by the sorbents (or $m_{\mathrm{H}_{2} \mathrm{~S}}^{\text {sorbent }}$ ); (b) Times for the complete removal of $\mathrm{H}_{2} \mathrm{~S}\left(t_{100 \%}\right)$ and breakthrough time $\left(t_{b t h}\right)$. 

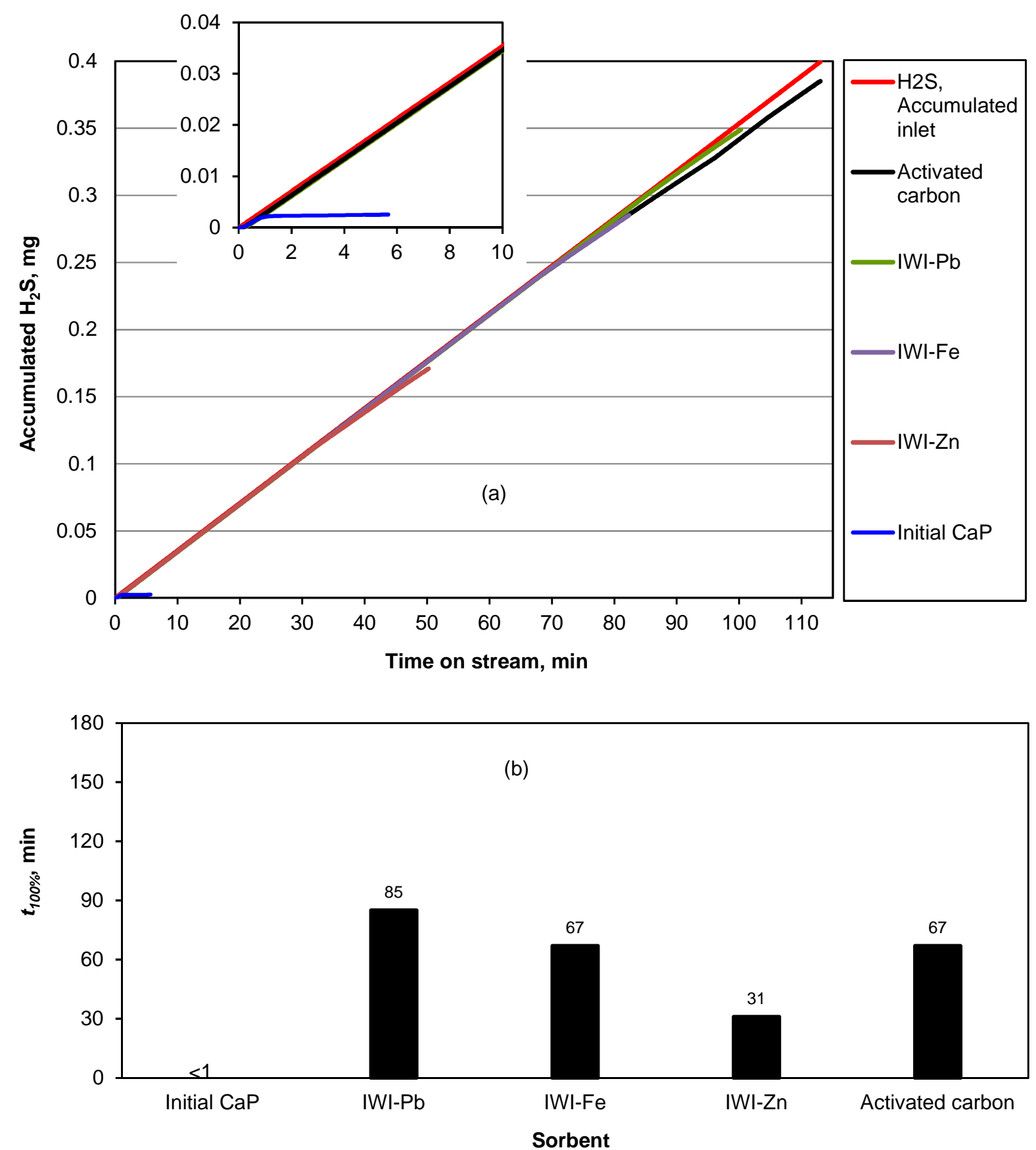

Figure 6. Performance of the prepared sorbents and an activated carbon as reference for the removal of $\mathrm{H}_{2} \mathrm{~S}$ (50 ppmv) diluted in air. Experimental conditions: room temperature and pressure, $500 \mathrm{mg}$ of sorbent, $50 \mathrm{~mL} / \mathrm{min}$ of gas effluent. (a): “ $\mathrm{H}_{2} \mathrm{~S}$, Accumulated inlet" curve: total quantity of $\mathrm{H}_{2} \mathrm{~S}$ injected in the reactor (or $m_{\mathrm{H}_{2} \mathrm{~S}}^{\text {inlet }}$ ); other curves: total quantities of $\mathrm{H}_{2} \mathrm{~S}$ captured by the sorbents (or $m_{H_{2} S}^{\text {sorbent }}$ ); (b): Times for the complete removal of $\mathrm{H}_{2} \mathrm{~S}\left(t_{100 \%}\right)$. 


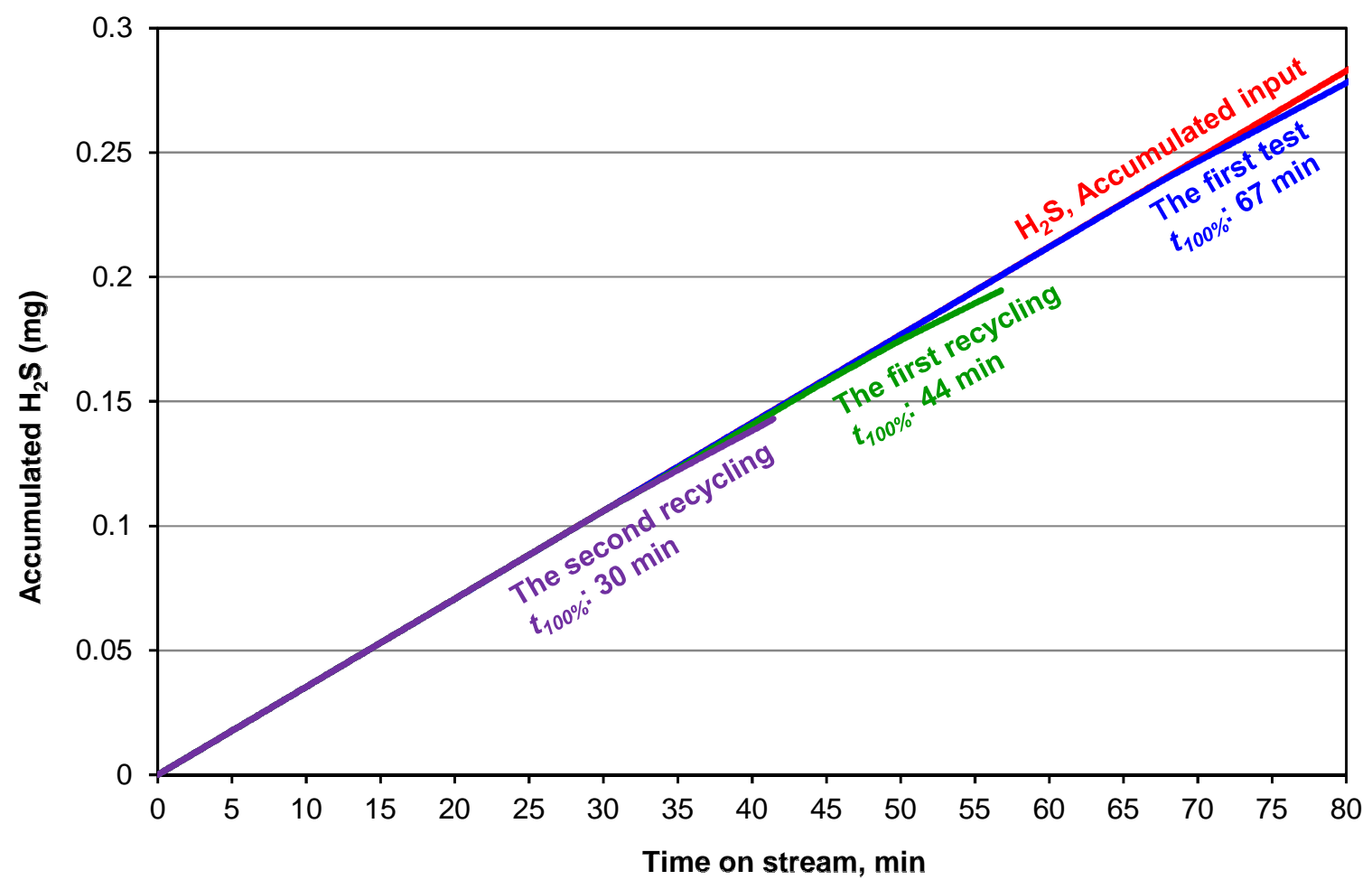

Figure 7. Regeneration study of the saturated IWI-Fe sorbent for the removal of $\mathrm{H}_{2} \mathrm{~S}$ (50 ppmv) diluted in air. Regeneration procedure: calcination of saturated sorbent in air atmosphere at $500{ }^{\circ} \mathrm{C}$. Experimental conditions: room temperature and pressure, $500 \mathrm{mg}$ of sorbent, $50 \mathrm{~mL} / \mathrm{min}$ of gas effluent. " $\mathrm{H}_{2} \mathrm{~S}$, Accumulated inlet" curve: total quantity of $\mathrm{H}_{2} \mathrm{~S}$ injected in the reactor (or $m_{\mathrm{H}_{2} \mathrm{~S}}^{\text {inlet }}$ ); other curves: total quantities of $\mathrm{H}_{2} \mathrm{~S}$ captured by the sorbents (or $m_{H_{2} S}^{\text {sorbent }}$ ). 


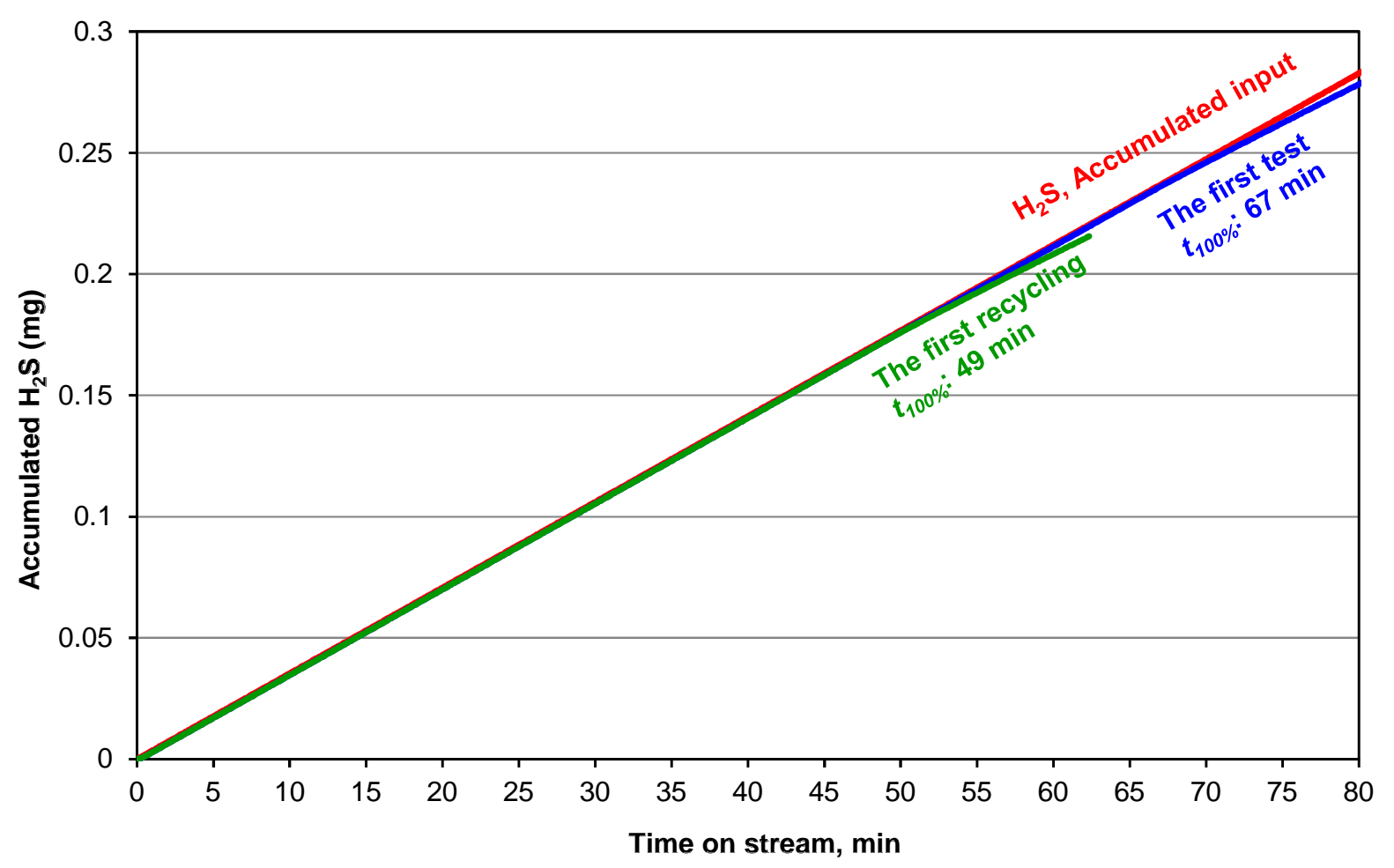

Figure 8. Regeneration study of the saturated activated carbon sorbent for the removal of $\mathrm{H}_{2} \mathrm{~S}$ $(50 \mathrm{ppmv})$ diluted in air. Regeneration procedure: calcination of saturated sorbent in air atmosphere at $500{ }^{\circ} \mathrm{C}$. Experimental conditions: room temperature and pressure, $500 \mathrm{mg}$ of sorbent, $50 \mathrm{~mL} / \mathrm{min}$ of gas effluent. " $\mathrm{H}_{2} \mathrm{~S}$, Accumulated inlet" curve: total quantity of $\mathrm{H}_{2} \mathrm{~S}$ injected in the reactor (or $m_{\mathrm{H}_{2} \mathrm{~S}}^{\text {inlet }}$ ); other curves: total quantities of $\mathrm{H}_{2} \mathrm{~S}$ captured by the sorbents (or $m_{H_{2} S}^{\text {sorbent }}$ ). 